\title{
Simultaneous bilateral testicular metastases from renal clear cell carcinoma: A case report and review of the literature
}

\author{
SHINGO MORIYAMA ${ }^{1}$, HIDEKI TAKESHITA ${ }^{1}$, AKIKO ADACHI $^{2}$, YOSHIAKI ARAI $^{3}$, SAORI HIGUCHI $^{1}$, \\ TAKUO TOKAIRIN $^{2}$, KOJI CHIBA ${ }^{1}$, KOJI NAKAGAWA ${ }^{4}$ and AKIRA NORO $^{1}$ \\ Departments of ${ }^{1}$ Urology and ${ }^{2}$ Pathology, Saitama Red Cross Hospital, Saitama, Saitama 338-8553; \\ ${ }^{3}$ Department of Urology, Nishi-Ohmiya Hospital, Saitama City, Saitama 330-0856; \\ ${ }^{4}$ Department of Surgery, Saitama Red Cross Hospital, Saitama City, Saitama 338-8553, Japan
}

Received June 18, 2013; Accepted December 17, 2013

DOI: $10.3892 / \mathrm{ol} .2014 .1830$

\begin{abstract}
Metastasis from renal cell carcinoma (RCC) to the testis is rare. This case report presented an extremely rare case of simultaneous bilateral testicular metastases from RCC in a 65-year-old man who had experienced indolent scrotal enlargement over a period of several months. Scrotal ultrasonography showed 4.0- and 2.0-cm-sized masses in the left and right testes, respectively. Contrast-enhanced computed tomography identified multiple tumors in the kidneys, the pancreas and the left adrenal gland. Left orchiectomy and pathological examination were performed and indicated testicular metastasis from clear cell RCC. The patient underwent complete surgical resection of all residual lesions. Postoperative follow-up examination without adjuvant therapy identified no recurrence over 11 months. This study also reviewed existing literature and determined that retrograde venous spread from the primary kidney tumor to the testis may be an important pathway for testicular metastasis from RCC. In conclusion, RCC can result in testicular metastases not only unilaterally, but also bilaterally, as was observed in the present case.
\end{abstract}

\section{Introduction}

Secondary neoplasms of the testis are rare, with an incidence of $0.9 \%$ in all testicular tumors according to a previous German survey (1). The most common location of the primary neoplasm is the prostate, followed by the gastrointestinal tract, lungs and kidneys (2-4). Renal cell carcinoma (RCC) commonly results in metastases to various organs. Although RCC metastasis is frequently observed in the lungs, lymph nodes, bones, liver and the brain, it is rarely identified in the testes $(5,6)$. Several cases of unilateral testicular metastasis from RCC have been

Correspondence to: Dr Shingo Moriyama, Department of Urology, Saitama Red Cross Hospital, 8-3-33 Kamiochiai, Chuo Ward, Saitama City, Saitama 338-8553, Japan

E-mail: zodiac_507@hotmail.com

Key words: renal cell carcinoma, metastasis, testicular neoplasm reported (1,7). Dieckmann et al (1) reported 13 cases of unilateral testicular metastases with detailed clinical information. They speculated that testicular metastases have left lateral dominance by analysing unilateral cases. However, simultaneous bilateral testicular metastases have not yet been determined. This report presented an extremely rare case of pathologically proven simultaneous bilateral testicular metastases from RCC. In addition, this study reviewed the previously reported cases of testicular metastases from RCC.

\section{Case report}

A 65-year-old man was referred to the Saitama Red Cross Hospital (Saitama, Japan) with a complaint of indolent left scrotal enlargement over several months. Physical examination revealed a stony, hard, hen's egg-sized mass in the left scrotum. A normal-sized testis with a small nodule was observed in the contralateral scrotum. Superficial lymph nodes were not palpable. Serum levels of $\alpha$-fetoprotein, $\beta$-human chorionic gonadotropin and soluble interleukin-2 receptor were all within normal limits. Scrotal ultrasonography revealed a $4.0 \times 3.3-\mathrm{cm}$ mass in the left testis and a $2.0 \times 1.7-\mathrm{cm}$ mass in the right testis. Contrast-enhanced computed tomography of the abdomen identified multiple tumors in the two kidneys, the pancreas and the left adrenal gland, in addition to the testes (Fig. 1). Imaging studies did not show metastasis in other regions, such as the bone, lungs and brain.

We performed left orchiectomy for pathological diagnosis. The resected testis contained a yellowish-white tumor with clear margins accompanied by parenchymal hemorrhage. Pathological examination revealed that the tumor cells had small, slightly oval nuclei with optically clear cytoplasm and were arranged in nests separated by a rich network of sinusoidal vascular channels (Fig. 2). These results were compatible with a diagnosis of metastasis from clear cell RCC. The patient was diagnosed with right RCC that was metastasizing to the contralateral kidney and adrenal gland, the pancreas and the testes (staging, cT1bN0M1).

All disseminated tumors were surgically resectable and the patient's general condition was good. Therefore, the patient underwent partial pancreatectomy, left adrenalectomy and left partial nephrectomy, followed by right radical 
Table I. Testicular metastasis from renal cell carcinoma: review of the literature.

\begin{tabular}{|c|c|c|c|c|c|c|c|}
\hline \multirow[b]{2}{*}{$\begin{array}{l}\text { Case } \\
\text { no. }\end{array}$} & \multirow[b]{2}{*}{ Author } & \multirow[b]{2}{*}{ Year } & \multirow[b]{2}{*}{$\begin{array}{l}\text { Age, } \\
\text { years }\end{array}$} & \multicolumn{3}{|c|}{ Laterality } & \multirow[b]{2}{*}{$\begin{array}{l}\text { Solitary or multiple } \\
\text { metastases }\end{array}$} \\
\hline & & & & Testis & Kidney & $\begin{array}{l}\text { Association between } \\
\text { the testis and the kidney }\end{array}$ & \\
\hline 1 & Bandler and Roen & 1946 & 47 & $\mathrm{R}$ & $\mathrm{R}$ & Ipsilateral & Solitary \\
\hline 2 & Tuchschmid & 1965 & 58 & $\mathrm{~L}$ & $\mathrm{~L}$ & Ipsilateral & Solitary \\
\hline 3 & Hanash et al & 1969 & 70 & $\mathrm{R}$ & $\mathrm{R}$ & Ipsilateral & NA \\
\hline 4 & Talerman and Kniestedt & 1974 & 68 & $\mathrm{~L}$ & $\mathrm{~L}$ & Ipsilateral & Solitary \\
\hline 5 & Nataf et al & 1975 & 64 & $\mathrm{~L}$ & $\mathrm{R}$ & Contralateral & Solitary \\
\hline 6 & Nataf et al & 1975 & 55 & $\mathrm{R}$ & $\mathrm{L}$ & Contralateral & Multiple \\
\hline 7 & DeBre et al & 1980 & 63 & $\mathrm{~L}$ & $\mathrm{R}$ & Contralateral & Solitary \\
\hline 8 & Post and Kassis & 1980 & 64 & $\mathrm{~L}$ & $\mathrm{~L}$ & Ipsilateral & Solitary \\
\hline 9 & Minervini et al & 1984 & 56 & $\mathrm{~L}$ & $\mathrm{~L}$ & Ipsilateral & Solitary \\
\hline 10 & Yano et al & 1985 & 62 & $\mathrm{~L}$ & $\mathrm{~L}$ & Ipsilateral & Multiple \\
\hline 11 & Ishizuka et al & 1986 & 71 & $\mathrm{~L}$ & $\mathrm{~L}$ & Ipsilateral & Multiple \\
\hline 12 & De Riese et al & 1986 & 60 & $\mathrm{~L}$ & $\mathrm{~L}$ & Ipsilateral & Multiple \\
\hline 13 & Dieckmann et al & 1988 & 73 & $\mathrm{~L}$ & $\mathrm{~L}$ & Ipsilateral & Multiple \\
\hline 14 & Indudhara et al & 1990 & 67 & $\mathrm{~L}$ & $\mathrm{~L}$ & Ipsilateral & Solitary \\
\hline 15 & Daniels et al & 1991 & 87 & $\mathrm{R}$ & $\mathrm{L}$ & Contralateral & Solitary \\
\hline 16 & Ribalta et al & 1993 & 62 & $\mathrm{R}$ & $\mathrm{R}$ & Ipsilateral & Multiple \\
\hline 17 & Blasco et al & 1994 & 72 & $\mathrm{~L}$ & $\mathrm{~L}$ & Ipsilateral & Solitary \\
\hline 18 & Lauro et al & 1998 & 56 & $\mathrm{R}$ & $\mathrm{L}$ & Contralateral & Solitary \\
\hline 19 & Steiner et al & 1999 & 66 & $\mathrm{~L}$ & $\mathrm{R}$ & Contralateral & Solitary \\
\hline 20 & Nabi et al & 2001 & 60 & $\mathrm{R}$ & $\mathrm{L}$ & Contralateral & Solitary \\
\hline 21 & Datta et al & 2001 & 81 & $\mathrm{R}$ & NA & NA & Multiple \\
\hline 22 & Datta et al & 2001 & 67 & $\mathrm{~L}$ & $\mathrm{R}$ & Contralateral & Solitary \\
\hline 23 & Datta et al & 2001 & 85 & $\mathrm{R}$ & $\mathrm{R}$ & Ipsilateral & Solitary \\
\hline 24 & Datta et al & 2001 & 53 & $\mathrm{R}$ & NA & NA & Multiple \\
\hline 25 & Marquez et al & 2001 & 65 & $\mathrm{R}$ & $\mathrm{R}$ & Ipsilateral & Solitary \\
\hline 26 & Nemoto et al & 2007 & 56 & $\mathrm{R}$ & NA & NA & Multiple \\
\hline 27 & Camerini et al & 2007 & 46 & $\mathrm{R}$ & $\mathrm{R}$ & Ipsilateral & Multiple \\
\hline 28 & Llarena et al & 2008 & 57 & $\mathrm{R}$ & $\mathrm{R}$ & Ipsilateral & Multiple \\
\hline 29 & Schmorl et al & 2008 & 66 & $\mathrm{R}$ & $\mathrm{R}$ & Ipsilateral & Multiple \\
\hline 30 & Hai-yang et al & 2010 & 70 & $\mathrm{~L}$ & $\mathrm{R}$ & Contralateral & Multiple \\
\hline 31 & Present case & 2013 & 65 & Bilateral & $\mathrm{R}$ & Bilateral & Multiple \\
\hline
\end{tabular}

R, right; L, left; NA, not available.

nephrectomy and right partial orchiectomy. Complete surgical resection was achieved. The pathological findings of the resected tumors were compatible with metastases from the right RCC (clear cell carcinoma, Grade II, pT1b). Postoperative follow-up examination without adjuvant therapy showed no recurrence for 11 months. The patient provided written informed consent.

\section{Discussion}

Secondary neoplasms of the testis are rare with a reported incidence of testicular metastasis of $0.02 \%$ (8) and $0.06 \%$ (2) at autopsy and testicular metastasis accounted for $0.9 \%$ of all types of testicular tumors (1). Table I summarized 30 cases of testicular metastasis from RCC. Bilateral testicular metastasis from RCC has not been previously reported. However, several cases of bilateral testicular metastases from prostate cancer (9) and colorectal cancer (10) have been determined.

Although RCC commonly results in metastases to various organs, it rarely spreads to the testes. The testes are regarded as a 'tumor sanctuary', as it has been hypothesized that tumor cells are not able to grow easily in that environment. The relatively low temperature of the scrotum could provide unacceptable conditions for the establishment of metastatic tumor cells (5). Additionally, the presence of the blood-testis barrier formed by Sertoli cells, which physiologically aims to protect spermatozoa, may also play an indirect role in the prevention of testicular metastasis (6).

This study also searched previous medical literature using the Medline/PubMed databases and identified 30 reported 


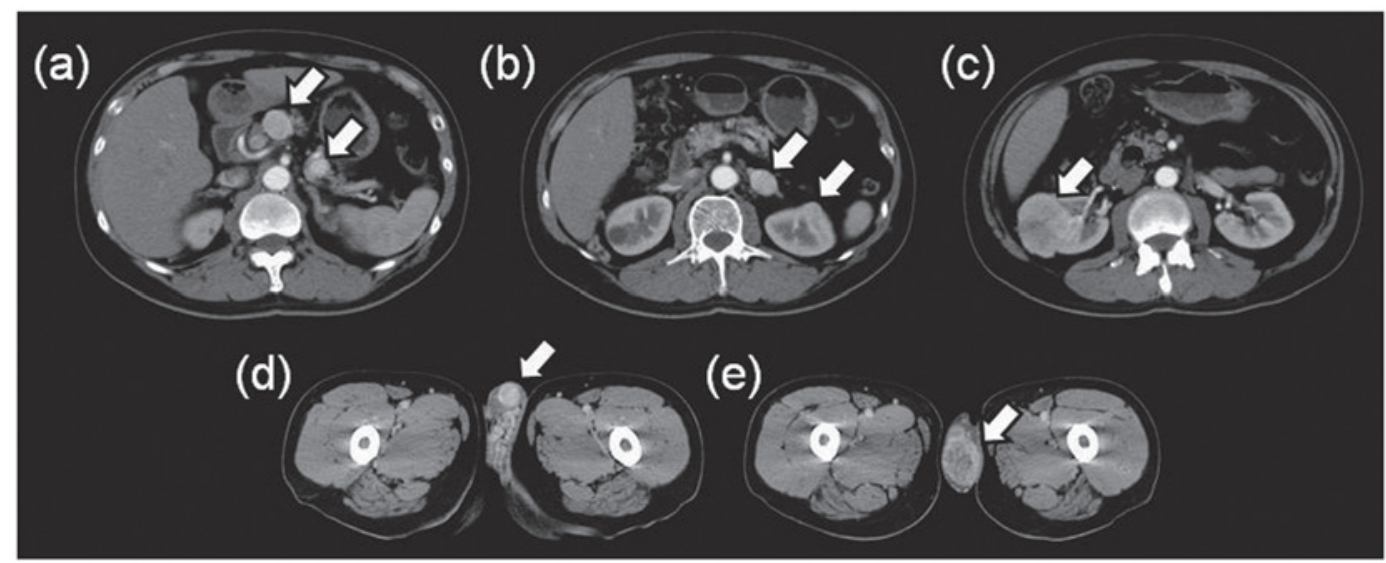

Figure 1. Abdominal computed tomography showing multiple tumors in various organs (arrows), including the (a) pancreas, (b) left adrenal gland and left kidney, (c) right kidney, (d) right testis and (e) left testis.

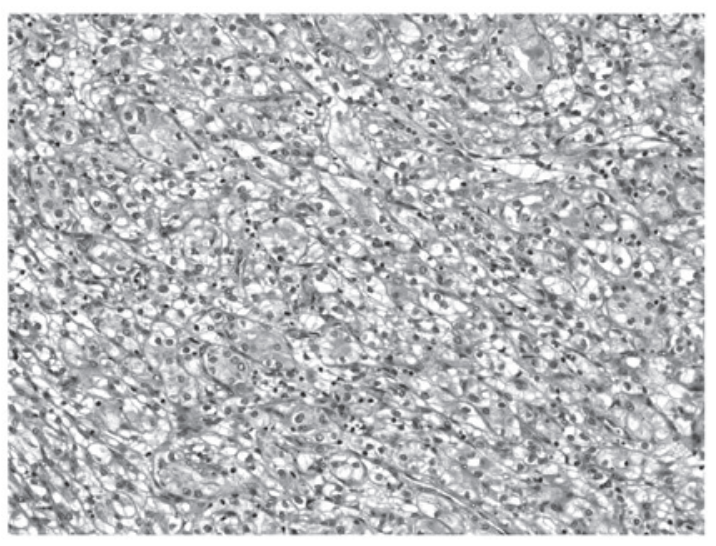

Figure 2. Microscopic section of the left testicular tumor shows a typical pattern of clear cell renal carcinoma. All the disseminated lesions, which were surgically resected, showed the same findings (hematoxylin and eosin, magnification, $\mathrm{x} 200)$.

cases of unilateral testicular metastasis from RCC, excluding autopsy cases (Table I). Of the 30 cases, 15 were of left testicular metastases (50\%) and 15 were of right testicular metastases (50\%). Although the left side is thought to be involved more often than the right side $(1,11)$, we did not observe any particular laterality of testicular metastasis. The association between primary kidney tumors and the testis totaled 18 ipsilateral metastases and nine contralateral metastases. Due to the tendency of metastasis from the kidney to the testis on the same side, there may be important spreading routes between the kidney and the testis. One of main routes could be a retrograde venous spread via the spermatic vein $(1,2,8)$. In the present case, the primary kidney and the larger testicular metastasis had the same laterality; therefore, superiority of ipsilateral metastasis was suggested.

In conclusion, to the best of our knowledge, this study was the first to present an extremely rare case of simultaneous bilateral testicular metastases from RCC. Following a review of the current literature, ipsilateral testicular metastasis from $\mathrm{RCC}$ is more frequent and, thus, retrograde venous spread via the spermatic vein may be one of the main pathways of testicular metastasis from RCC. As demonstrated in this case, RCC can result in testicular metastasis, not only unilaterally but also bilaterally.

\section{References}

1. Dieckmann KP, Düe W and Loy V: Intrascrotal metastasis of renal cell carcinoma. Case reports and review of the literature. Eur Urol 15: 297-301, 1988.

2. Pienkos EJ and Jablokow VR: Secondary testicular tumors. Cancer 30: 481-485, 1972.

3. Dutt N, Bates AW and Baithun SI: Secondary neoplasms of the male genital tract with different patterns of involvement in adults and children. Histopathology 37: 323-331, 2000.

4. Haupt HM, Mann RB, Trump DL and Abeloff MD: Metastatic carcinoma involving the testis. Clinical and pathologic distinction from primary testicular neoplasms. Cancer 54: 709-714, 1984.

5. Blefari F, Risi O and Pino P: Secondary tumors of testis: two rare cases and review of the literature. Urol Int 48: 469-470, 1992

6. Camerini A, Tartarelli G, Martini L, Donati S, Puccinelli P and Amoroso D: Ipsilateral right testicular metastasis from renal cell carcinoma in a responder patient to interleukine- 2 treatment. Int J Urol 14: 259-260, 2007.

7. Datta MW, Ulbright TM and Young RH: Renal cell carcinoma metastatic to the testis and its adnexa: a report of five cases including three that accounted for the initial clinical presentation. Int J Surg Pathol 9: 49-56, 2001.

8. Hanash KA, Carney JA and Kelalis PP: Metastatic tumors to testicles: routes of metastasis. J Urol 102: 465-468, 1969.

9. Giannakopoulos X, Bai M, Grammeniatis E, Stefanou D and Agnanti N: Bilateral testicular metastasis of an adenocarcinoma of the prostate. Ann Urol 28 (Paris): 274-276, 1994 (In French).

10. Hatoum HA, Abi Saad GS, Otrock ZK, Barada KA and Shamseddine AI: Metastasis of colorectal carcinoma to the testes: clinical presentation and possible pathways. Int J Clin Oncol 16: 203-209, 2011.

11. Nabi G, Gania MA and Sharma MC: Solitary delayed contralateral testicular metastasis from renal cell carcinoma. Indian J Pathol Microbiol 44: 487-488, 2001. 